Original Research

\title{
Pembuatan Mobile Apps Berbasis Android dengan Memanfaatkan Geolokasi untuk Pengawasan Proses Belajar Siswa
}

\author{
Elvredo Kinsey $\operatorname{Tjan}^{1 *}$, Daniel Hary Prasetyo ${ }^{1}$, Felix Handani ${ }^{1}$ \\ ${ }^{1}$ jurusan Teknik Informatika, Fakultas Teknik, Universitas Surabaya, Raya Kalirungkut Surabaya- \\ Indonesia 60293 \\ * corresponding author: s160415103@student.ubaya.ac.id
}

\begin{abstract}
Non-formal education often requires children to travel to have face-to-face meetings with their teachers. Meetings that take place often still use the attendance method manually by using the attendance form, thus allowing the loss of attendance form, errors in making attendance, and allowing fraud in doing attendance. Parents also cannot control the location of their children when attending meetings and do not know who the tutoring service is who is the teacher for their child. Based on these problems, a mobile application was created that can be used by students, teachers, and parents. Where the attendance process is done digitally by students by taking selfies through a smartphone camera. Teachers do not need to bother in recapitulating attendance and save time when the attendance process is carried out by students. Parents can find out the child's location, receive notifications when the child makes attendance, and download meeting attendance reports. The trial was carried out privately by providing input and seeing the output results whether it had gone well. Validation is done by conducting interviews with each user with the roles of parents, teachers, and students who have tried the system. Based on the results of trials and validation conducted with interviews, it was found that the system that has been created to supervise the student learning process is running well and helps parents in controlling face-to-face meetings between students and teachers through notifications received by parents when students make a presence, attendance reports that help teachers recap attendance data and help teachers make appointments with students easier to do.
\end{abstract}

Keywords: education, attendance, mobile application, camera, notification

\begin{abstract}
Abstrak - Pendidikan non-formal sering kali mengharuskan anak bepergian untuk melakukan pertemuan tatap muka dengan guru mereka. Pertemuan yang berlangsung sering kali masih menggunakan metode presensi secara manual dengan menggunakan form presensi, sehingga memungkinkan terjadinya hilangnya form presensi, kesalahan dalam melakukan presensi, dan memungkinkan terjadinya kecurangan dalam melakukan presensi kehadiran. Orang tua juga tidak dapat mengontrol lokasi anak saat mengikuti pertemuan dan tidak mengetahui siapa jasa pengajar yang menjadi pengajar bagi anak mereka. Berdasarkan permasalahan tersebut dibuatkan sebuah aplikasi mobile yang dapat digunakan siswa, guru, dan orang tua. Dimana proses presensi dilakukan secara digital oleh siswa dengan mengambil foto selfie melalui kamera smartphone. Guru tidak perlu repot dalam melakukan rekapitulasi presensi kehadiran dan menghemat waktu saat proses presensi dilakukan siswa. Orang tua dapat mengetahui lokasi anak, menerima notifikasi ketika anak melakukan presensi, dan mengunduh laporan presensi pertemuan. Uji coba dilakukan secara pribadi dengan memberikan inputan dan melihat hasil output apakah telah berjalan dengan baik. Validasi dilakukan dengan cara melakukan interview kepada setiap pengguna dengan peran orang tua, guru, dan siswa yang telah mencoba sistem. Berdasarkan hasil uji coba dan validasi yang dilakukan dengan interview diperoleh bahwa sistem yang telah dibuat untuk melakukan pengawasan terhadap proses belajar siswa berjalan dengan baik dan membantu orang tua dalam mengontrol pertemuan tatap muka yang dilakukan siswa dengan guru melalui notifikasi yang diterima orang tua saat siswa melakukan presensi, laporan presensi yang membantu guru dalam merekap data presensi kehadiran dan membantu guru untuk membuat janji pertemuan dengan siswa menjadi lebih mudah untuk dilakukan.
\end{abstract}

Kata kunci: pendidikan, presensi, aplikasi mobile, kamera, notifikasi

\section{PENDAHULUAN}

Pendidikan merupakan suatu keharusan bagi setiap orang. Pendidikan selalu mengalami perubahan, perkembangan dan penyesuaian berdasarkan perkembangan di bidang kehidupan. Perubahan dan penyesuaian ini meliputi berbagai komponen seperti kompetensi guru sebagai tenaga pendidik, sarana dan prasarana pendidikan dan mutu pendidikan dengan upaya agar kualitas pendidikan dapat ditingkatkan menjadi lebih baik.

Perkembangan yang terjadi saat ini membuat banyak penyedia jasa pendidikan baik secara formal maupun non-formal yang berlomba-lomba untuk menawarkan jasa pendidikan dengan mutu pendidikan yang tinggi, tenaga pendidik yang berkompeten dan dengan sarana dan prasarana yang baik. Dalam hal sarana dan prasarana tentu setiap jasa pendidikan 
memiliki layanan yang berbeda-beda sesuai dengan kondisi dan situasi dari perkembangan bidang kehidupan untuk meningkatkan kualitas jasa pendidikan. Dapat diketahui sekarang ini kota besar seperti Surabaya sering mengalami kemacetan. Kemacetan yang ditimbulkan tentu saja menjadi suatu tantangan tersendiri bagi penyedia jasa pendidikan. Dari kendala kemacetan yang dialami pada kota-kota besar membuat beberapa jasa Pendidikan mengambil salah satu solusi yaitu menawarkan jasa pengajar untuk secara langsung datang ke rumah siswanya satu-persatu sehingga siswa dapat lebih fokus pada materi ketimbang memikirkan masalah non-teknis seperti macet dan jasa pengajar yang dapat mengajar pada tempat tertentu yang ditentukan untuk dilakukan proses pembelajaran.

Mekanisme yang ditawarkan oleh penyedia jasa pendidikan merupakan sesuatu yang baik, namun mekanisme yang ditawarkan ini membuat orang tua yang sibuk dalam pekerjaan tidak dapat memantau dengan baik siapa pengajar yang mengajar anaknya, lokasi tempat pembelajaran jika pembelajaran tidak di lakukan pada tempat jasa pendidikan, dan lokasi anaknya ketika mengikuti proses pembelajaran. Ditambah lagi jika orang tua yang sering memiliki pekerjaan yang mengharuskannya berada di luar kota, hal ini membuat orang tua tidak dapat memantau aktivitas anaknya. Mekanisme yang ditawarkan juga dapat membuat penyedia jasa pendidikan tidak mengetahui apakah aktivitas pembelajaran yang diberikan jasa pengajar kepada siswa telah berjalan dengan baik.

Kesibukan yang dimiliki orang tua dan kurangnya kontrol terhadap jasa pengajar dapat berdampak pada perkembangan pembelajaran siswa. Oleh karena itu diperlukan sebuah sistem yang dapat memberikan umpan balik kepada orang tua dan penyedia jasa pendidikan, sehingga orang tua dapat mengetahui lokasi dan perkembangan anak melalui laporan yang disediakan dan penyedia jasa pendidikan juga dapat mengetahui aktivitas jasa pengajar dalam memberikan materi pembelajaran.

Sistem dengan memanfaatkan geolokasi untuk pengawasan proses belajar siswa ini akan dibatasi oleh ruang lingkup dalam proses pembuatan sistem. Ruang lingkup bertujuan untuk membatasi proses pembuatan sistem seperti fitur yang dibuat pada sistem. Ruang lingkup tersebut di antaranya adalah :

1. Perangkat yang digunakan adalah smartphone dengan sistem operasi Android.

2. Database yang akan digunakan adalah MySQL.

3. Menggunakan Bahasa Pemrograman Java.

4. Penelitian yang dilakukan hanya difokuskan pada penggunaan teknologi GPS yang tersedia pada smarphone android versi 5.0 (Lollipop) atau keatas.

5. Laporan pencatatan kehadiran siswa berupa waktu, tenaga pengajar dan lokasi pembelajaran yang dapat diunduh berupa file PDF dan Excel.

\section{METODE}

Penelitian yang dilakukan sebelum proses pembuatan sistem bertujuan untuk mengumpulkan informasi atau data yang berguna dan bermanfaat bagi pembuatan sistem. Informasi dan data ini nantinya akan diproses lebih lanjut sebagai acuan dalam proses pembuatan sistem.

Metode Penelitian yang dilakukan memiliki beberapa tahapan yang akan dilakukan. Setiap tahapan akan memberikan informasi lebih lanjut sehingga dapat mempermudah dalam proses pembuatan sistem. Metode penelitian dalam pembuatan sistem ini sebagai berikut :

\section{Persiapan}

Persiapan yang dilakukan dalam pembuatan mobile apps dengan memanfaatkan geolokasi untuk membantu pembelajaran siswa berbasis Android yaitu dengan mengumpulkan berbagai informasi terkait yang dapat membantu terbentuknya suatu sistem yang baik dengan memanfaatkan beberapa sumber seperti buku, jurnal, artikel, dan internet. 


\section{Analisis}

Analisis sistem yang dilakukan saat ini dengan mempelajari penggunaan teknologi GPS pada smartphone untuk memperoleh titik lokasi berupa garis bujur dan garis lintang dari sebuah smartphone dan melakukan survei terhadap metode presensi yang digunakan saat ini. Dari informasi yang didapatkan maka akan diketahui gambaran sistem yang akan dibuat.

\section{Desain}

Desain dilakukan sebagai rancangan awal dalam pembuatan mobile apps. Desain tersebut dibuat secara urut mulai dari desain data, desain proses, dan User Interface (UI) atau desain tampilan yang nantinya digunakan dalam pembuatan mobile app.

4. Implementasi

Tahap ini merupakan tahap di mana dilakukannya proses pembuatan mobile apps berdasarkan persiapan dan pendukung yang diperoleh melalui hasil analisis, desain yang dilakukan, dan ruang lingkup yang telah dibuat sehingga mobile apps dapat di buat sesuai dengan yang telah direncanakan.

\section{Uji Coba dan Evaluasi}

Pada tahap uji coba sistem akan dilakukan pengujian untuk mengetahui bahwa sistem berjalan dengan baik atau bebas error. Sedangkan pada tahap Evaluasi ini pengguna akan diminta untuk melakukan penggunaan terhadap sistem yang dibuat.

\section{Penyusunan Laporan}

Penyusunan dilakukan untuk membuat dokumentasi terhadap sistem. Dokumentasi yang dibuat meliputi cara penggunaan dan struktur sistem terkait dengan sistem yang dibuat.

\section{HASIL DAN BAHASAN}

\section{Kondisi Saat Ini}

Kondisi saat ini diperoleh dari hasil survei dan pengumpulan informasi mengenai aplikasi yang bertujuan untuk melakukan proses pengawasan pembelajaran. Dari hasil survei yang dilakukan untuk mengetahui penggunaan metode presensi pada bimbingan belajar nonformal adalah sebagian besar responden melakukan presensi dengan metode menggunakan "form" (kertas presensi) yaitu sebanyak 65 respons dari 70 orang responden dapat dilihat pada gambar 1 dan hasil survei untuk mengetahui tanggapan dari responden mengenai validitas metode presensi yang diterapkan pada lembaga bimbingan yang diikuti diperoleh bahwa masih sebanyak 22 responden memberikan tanggapan bahwa metode presensi yang diterapkan masih memiliki kemungkinan untuk terjadinya kesalahan dan masih dapat diakali karena tidak adanya umpan balik berupa laporan presensi yang dapat dilihat secara transparan yang ditunjukkan pada gambar 2. 


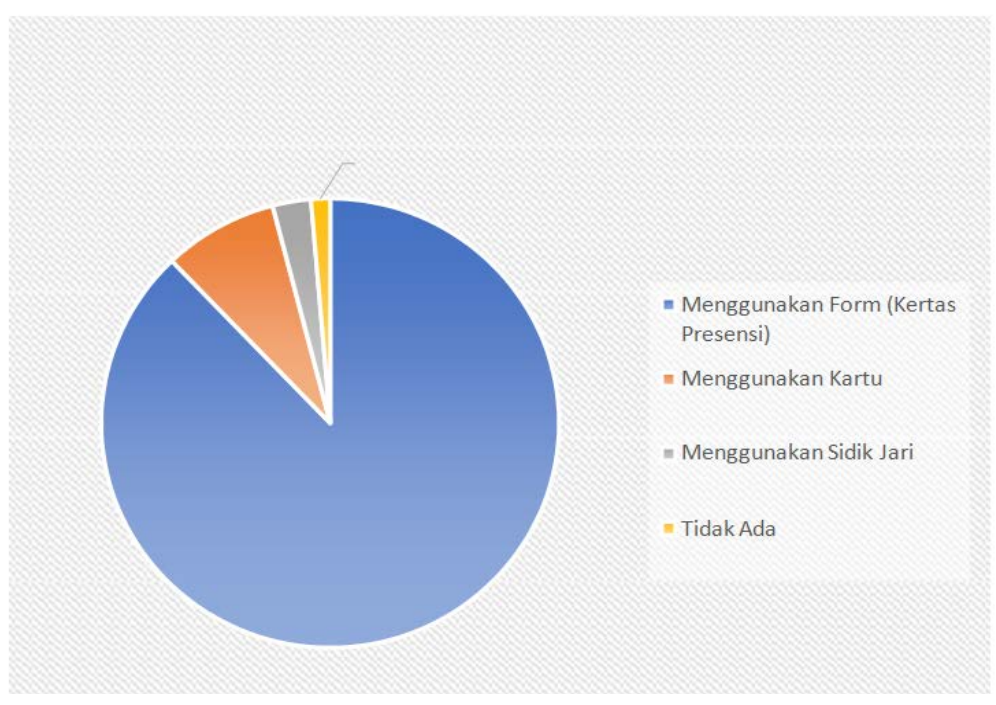

Gambar 1. Grafik lingkaran persentase metode presensi responden dalam mengikuti lembaga bimbingan belajar non-formal.

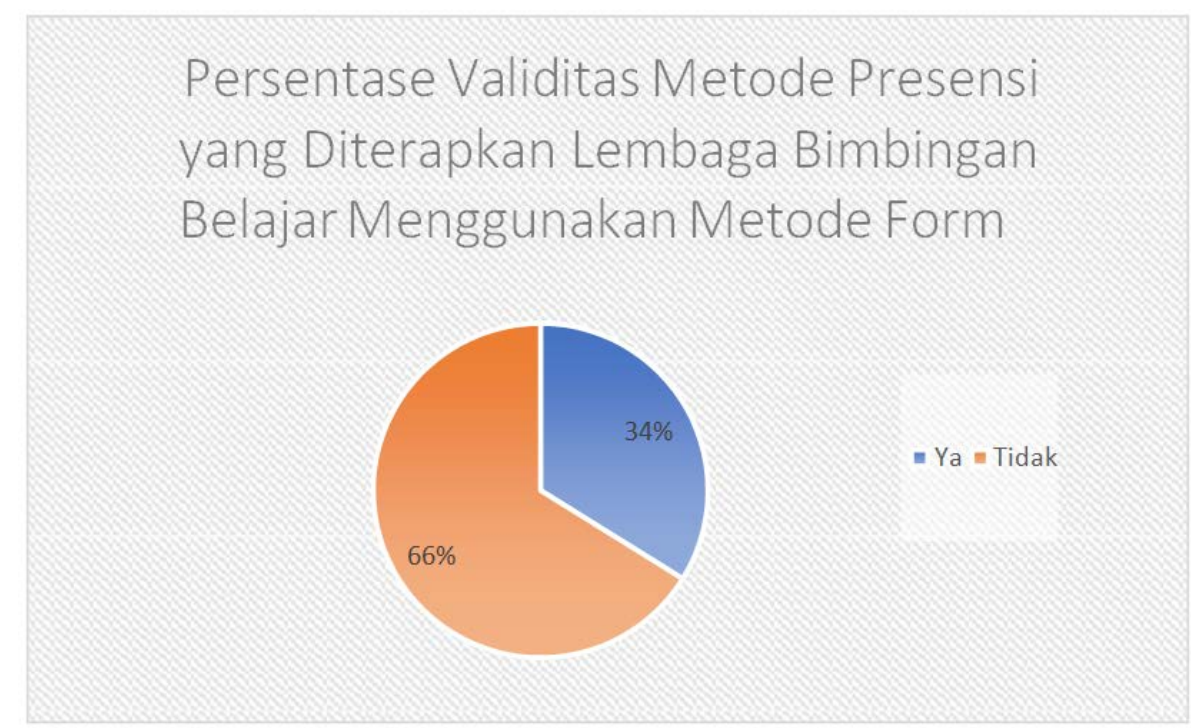

Gambar 2. Grafik lingkaran persentase validitas metode presensi Responden yang diterapkan lembaga bimbingan belajar non-formal dengan metode presensi menggunakan form.

Dari hasil pengumpulan informasi terhadap aplikasi yang bertujuan untuk melakukan pengawasan proses belajar siswa diperoleh bahwa belum adanya proses pengawasan terhadap presensi yang dilakukan pada proses pertemuan antara guru dan siswa. Pada halaman pertemuan yang diatur oleh guru masih kurang jelas seperti di mana lokasi pertemuan dilakukan yang ditunjukkan pada Gambar 3 dan juga tidak adanya notifikasi yang diberikan saat pertemuan dibuka. 


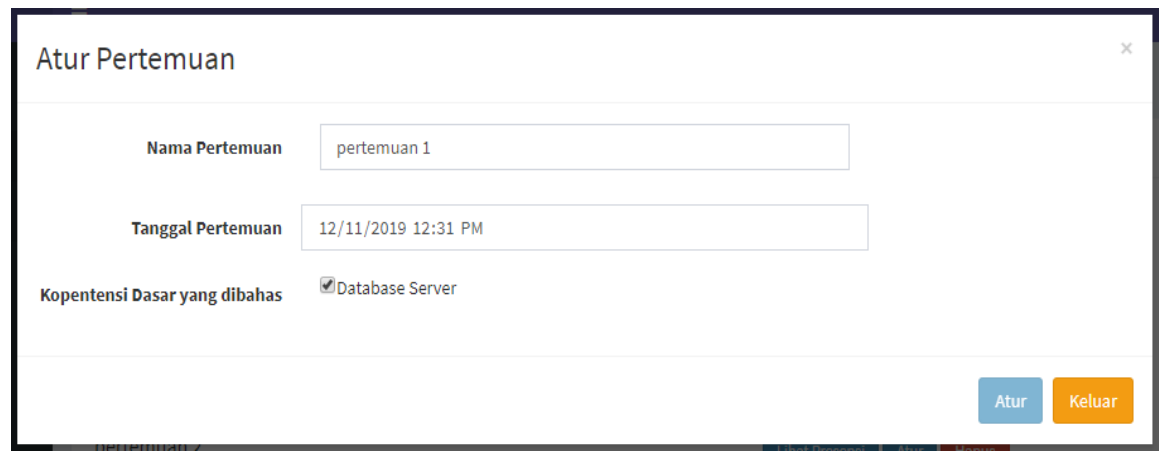

Gambar 3. Halaman atur pertemuan.

\section{Kebutuhan Sistem}

\section{- Login dan hak akses}

Pengguna yang menggunakan sistem akan dibedakan menjadi beberapa peran yaitu guru, siswa, orang tua, dan admin. Setiap peran akan memiliki fitur yang berbeda, sehingga tidak semua peran dapat mengakses fitur yang sama. Pengguna yang akan login ke sistem harus memasukkan email, password, dan peran pengguna.

\section{- Presensi dilakukan secara digital}

Presensi yang dilakukan secara digital ini menggunakan foto selfie yang diperoleh dari kamera smartphone masing-masing siswa. Presensi yang dilakukan secara digital bertujuan untuk mengurangi waktu yang diperlukan saat siswa melakukan presensi kehadiran, guru tidak perlu melakukan rekapitulasi secara manual, dan juga mengurangi penggunaan kertas yang memungkinkan hilangnya kertas atau rusaknya kertas presensi.

\section{- Verifikasi dan validasi secara digital}

Verifikasi dapat dilihat secara langsung oleh orang tua melalui mobile apps yang akan dibuat seperti melihat secara langsung foto selfie anak dan mengetahui geolokasi anak dan proses validasi dapat dilakukan oleh orang tua dengan mengunduh dan melihat laporan kehadiran anaknya.

\section{- Notifikasi}

Notifikasi digunakan untuk memberitahu siswa ketika pertemuan telah dibuka atau ditutup oleh guru. Notifikasi kepada orang tua dilakukan jika siswa telah melakukan presensi kehadiran.

\section{- Laporan}

Guru, orang tua, dan siswa dapat melihat laporan presensi yang diperoleh melalui kegiatan pertemuan yang dijadwalkan dan diikuti oleh siswa. Laporan yang diperoleh oleh pengguna berupa file soft copy dalam format excel dan $p d f$.

\section{Desain dan Implementasi}

Pembuatan mobile apps berbasis android dengan memanfaatkan geolokasi untuk pengawasan proses belajar siswa adalah sistem yang akan dibuat dan untuk perancangan pembuatan sistem diperlukan ERD, ERD memiliki entitas, atribut, dan relasi. Sebuah entitas yang dimiliki dalam ERD akan memiliki beberapa atribut dan setiap entitas yang ada terdapat pada ERD akan saling berhubungan satu dengan yang lainnya melalui adanya hubungan relasi yang menghubungkan entitas tersebut.

Desain ERD yang dibuat untuk membangun sistem memiliki 18 entitas.Setiap entitas yang dibuat merupakan entitas yang disesuaikan dengan sistem untuk menyimpan data keperluan sistem, sehingga sistem dapat berjalan dengan baik sesuai dengan data yang telah disimpan. 
Proses yang dilakukan setiap pengguna memiliki perbedaan sesuai hak akses yang dimiliki oleh pengguna. Desain BPMN yang digambarkan akan memiliki desain secara keseluruhan dan desain pembagian (subprocess) yang dilakukan oleh pengguna sesuai hak akses yang diterima yang ditunjukkan pada Gambar 4.

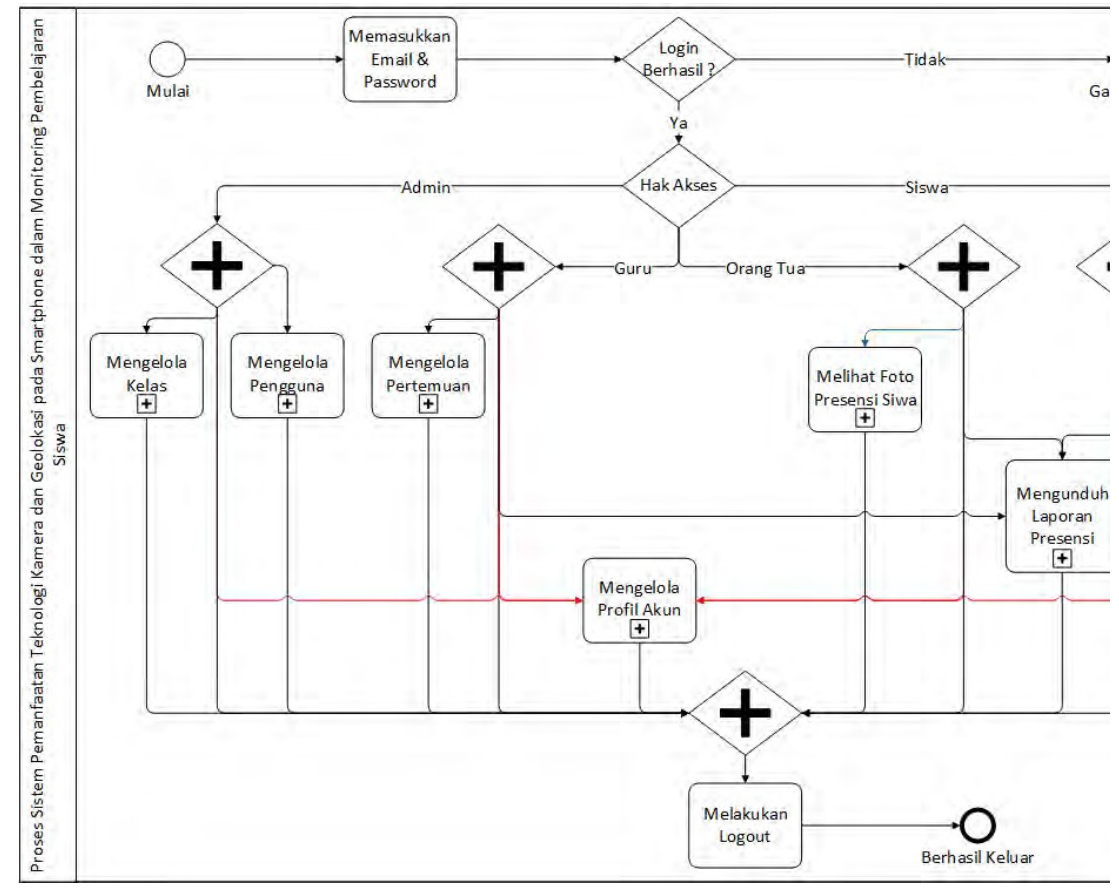

Gambar 4. Bpmn sistem keseluruhan.

Setelah selesai dengan desain data dan desain proses maka langkah berikutnya adalah desain tampilan atau user interface. Desain tampilan terdiri dari empat kategori pengguna yaitu admin, guru, siswa, dan orang tua. Untuk desain tampilan home admin dapat dilihat pada Gambar 5, untuk desain tampilan home guru dan siswa dapat dilihat pada Gambar 6 karena memiliki desain tampilan yang sama, untuk desain tampilan orang tua dapat dilihat pada Gambar 7.

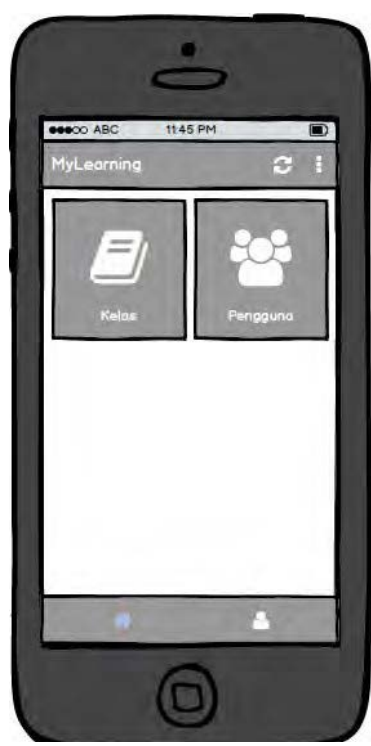

Gambar 5. Desain tampilan home admin. 


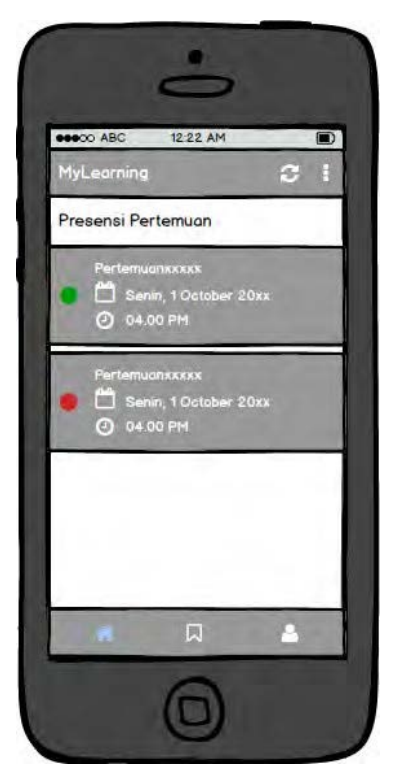

Gambar 6. Desain tampilan home guru dan siswa.

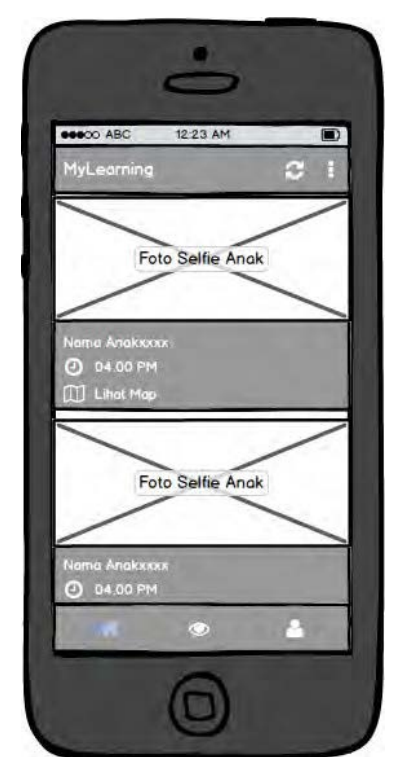

Gambar 7. Desain tampilan home orang tua.

\section{SIMPULAN}

Dari hasil uji coba dan validasi yang telah dilakukan diperoleh beberapa kesimpulan. Hasil kesimpulan yang didapatkan sebagai berikut :

1. Siswa dapat melakukan presensi kehadiran dengan mudah melalui kamera smartphone mereka secara pribadi.

2. Mempermudah proses rekap data presensi karena presensi dilakukan secara digital.

3. Membantu orang tua dalam mengawasi siswa dalam mengikuti pertemuan dan mengetahui lokasi siswa.

4. Mempermudah orang tua dalam memperoleh laporan presensi kehadiran di mana saja dan kapan saja.

Saran atau masukkan yang diperoleh dapat digunakan untuk pengembangan sistem menjadi lebih baik lagi ke depannya. Saran yang diperoleh antara lain : 
1. Sistem yang dibuat tidak hanya berjalan dan beroperasi pada sistem operasi android saja namun bisa juga dikembangkan ke beberapa sistem operasi lain seperti iOS.

2. Sistem dapat memiliki fitur chat yang dapat digunakan oleh setiap pengguna yaitu guru, orang tua, dan siswa.

\section{PUSTAKA ACUAN}

Kasman, Akhmad Dharma. (2018). Trik Kolaborasi Android dengan PHP \& MySQL. Yogyakarta : Lokomedia.

Schwaber, K., Sutherland, J. (2017). The Scrum Guide.

Wahana, Komputer. (2014). Membangun Aplikasi Mobile Cross Platform dengan Phonegap.

Yudhanto, Y \& Wijayanto, A. (2017). Mudah Membuat dan Berbisinis Aplikasi Android dengan Android Studio. Jakarta : PT Elex Media Komputindo. 